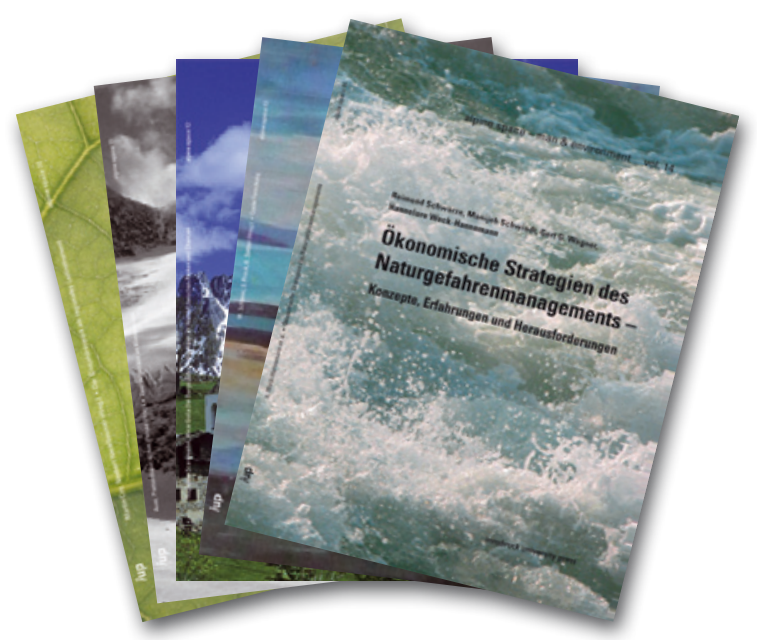

The University of Innsbruck was founded in 1669 and today, with more than 27000 students and 4000 staff and faculty members, is the largest and most important research and education institution in western Austria. Innsbruck is located in the middle of the Alps and its history, culture and economy are deeply influenced and shaped by mountains. Thus it is not surprising that the University of Innsbruck is focusing on mountain issues.

The Research Focus Alpine Space - Man \& Environment, established in 2010, is one of the three research foci of the University of Innsbruck, besides Molecular Biosciences and Physics. Consisting of nine research centres at eight faculties, the research focus covers a wide range of disciplines, from history to agriculture and from biology to socio-economics. Partners of the research focus are the Alpine Research Station (AFO) of the University of Innsbruck in Obergurgl, alpS the Centre for Climate Change and Adaptation Strategies, the Institute of Mountain Research: Man and Environment (IGF) at the Austrian Academy of Sciences and the European Academy of Bolzano / Bozen (EURAC) in South Tyrol (Italy).

Since 2006, the Research Focus, in cooperation with iup (innsbruck university press), publishes a series called alpine space - man and environment (series eds.: R. Psenner, R. Lackner, A. Borsdorf, H. Weck-Hannemann). These books, fourteen to date, deal with mountain issues of common interest, with the intention of reaching the general public. Some of the volumes listed below also contain information of particular interest for protected area management.

All articles can be downloaded for free from the homepage of the Research Focus (http://www.uibk. ac.at/alpinerraum/publications/). Printed versions at prices from $€ 12.50$ to $€ 19.90$ can be ordered from alpiner.raum@uibk.ac.at.

An average of 1000 downloads per day over the last two years documents the interest of the scientific community and the public at large. The publication series alpine space - man and environment can serve as best practice example of how to transfer scientific knowledge to the public.

\section{The publication series alpine space - man and environment - at the University of Innsbruck}

Volume 1: Die Alpen im Jahr 2020 / The Alps in 2020. Psenner, R. \& R. Lackner (eds.) 2006.

ISBN-13:978-3-902571-01-4, 121 pp.

This book summarizes in a generally understandable way results of an interdisciplinary workshop on What the Alps will possibly look like in 2020, held in October 2005 at the Alpine Research Center in Obergurgl. The articles offer a broad range of perspectives on cultural, social, economic and political developments in the Alps. (in German, one article in French)

Volume 2: Politische, kulturelle und wissenschaftliche Perspektiven der nachhaltigen Raumentwicklung in den Alpen / Political, cultural and scientific perspectives of sustainable spatial development in the Alps. Borsdorf, A. \& S. Lange (eds.) 2006.

ISBN 978-3-902571-02-1

The book summarizes initial results of the EU project DIAMONT (Data Infrastructure for the Alps, Mountain Orientated Network Technology), which was coordinated at the University of Innsbruck. (in German)

Volume 3: The Water Balance of the Alps: what do we need to protect the water resources of the Alps? Proceedings of the Conference 'The Water Balance of the Alps', 28-29 September 2006, Innsbruck (Austria). Psenner, R. \& R. Lackner (eds.) 2007.

ISBN 978-3-902571-33-5

The book summarizes the results of an interdisciplinary conference aimed at presenting the view of researchers as well as of administrators and to discuss the best way to protect sensitive waters, including ice and snow, in the Alps. (in English)

Volume 4: Ist es der Sindtfluss? Kulturelle Strategien \& Reflexionen zur Prävention und Bewältigung von Naturgefahren / Is it the deluge? Cultural strategies and reflections on preventing and handling natural risks. Lackner, R., R. Psenner \& M. Walcher (eds.) 2008. ISBN 978-3-902571-32-8

This volume documents a conference held in October 2006 at the Alpine Research Center in Obergurgl 
within the UNESCO convention on the protection of immaterial cultural heritage, which focused on the potential use and value of traditional knowledge, passed on or forgotten, about handling natural hazards and disasters. The articles published here are meant to encourage further discourses and new research approaches as a first step towards an interdisciplinary debate on and perception of cultural heritage. It should also contribute to a better appreciation of traditional knowledge as a future resource. (in German).

Volume 5: Über Almen: zwischen Agrikultur und Trashkultur/On mountain pastures: between agriculture and trash culture. Kirchengast, C. 2008.

ISBN 978-3-902571-46-5

This volume focuses on the value of mountain pastures for society in Austria. What is the relation of farmers to their mountain pastures - as part of their farms, their culture, history and future - and in what way do supraregional, national and global processes of change impact on the life worlds of farmers? (in German)

Volume 6: Klimawandel in Österreich. Die letzten 20000 Jahre... und ein Blick voraus / Climate change in Austria. The last 20000 years ... and a look ahead. Schmidt, R., C. Matulla \& R. Psenner (eds.) 2009.

ISBN 978-3-902571-89-2

More than 20 well-known Austrian climate experts from various disciplines present an overview of the currant state of knowledge in Austrian climate research - from the ice age to the modern warm period - and venture an outlook for the next 100 years and possible impacts on Austria. (in German)

Volume 7: Global Change and Sustainable Development in Mountain Regions. Proceedings of the COST Strategic Workshop, 7-9 April 2008, Innsbruck (Austria). Jandl, R. , A. Borsdorf, H. van Miegroet, R. Lackner \& R. Psenner (eds.) 2009.

ISBN 978-3-902571-97-7

The book summarizes results of a Strategic Workshop aimed at putting research topics on mountain ecosystem services on the political agenda and identifying the implications of climate and socio-economic change for current and future forms of land use. (in English)

Volume 8: Karl Außerhofer: Das Kriegstagebuch eines Soldaten im Ersten Weltkrieg. Wisthaler, S. 2010. ISBN 978-3-902571-90-8

The book is a scholarly edition of Karl Außerhofer's diary for the years 1914 to 1918 of his stationing in the Pustertal valley and on the southern front during the First World War. The diary includes texts on the weather, descriptions of landscapes, remarks on food, leisure, clothes / hygiene / accommodation, on illness and death, on emotions, self-perception and perception of the enemy, on families, civilians, an outlook and hopes for the future, on religious issues as well as on the force and the service. This volume aims to reduce the schism between history as science and history as something lived through by individuals and to complement and correct both perspectives. (in German)

Volume 9: Die Alpen - Einblicke in die Natur / The Alps - insights into nature. Hofer, R. (ed.) 2009.

ISBN 978-3-902719-02-7

A team of authors from the University of Innsbruck and other Tyrolean institutions presents an overview on the Alpine world in this volume. Across 26 chapters and 270 images, this book offers natives and tourists deeper insights into alpine habitats and their complex ecological interdependencies. A sequence of greatly varied habitats, from sundrenched lower slopes through forests up to the highest peaks of the Alps with their extreme conditions for living creatures. (in German)

Volume 10: Der Biosphärenpark als Leitinstrument / The biosphere reserve as managing instrument. Coy, M. \& N. Weixlbaumer (eds.) 2009.

ISBN 978-3-902719-20-1

This publication is based on the findings of a research project on future development strategies for Großes Walsertal Biosphere Reserve, funded by the Austrian National Committee of the UNESCO Programme Man and the Biosphere (MAB). The project analysed the regional economy and the geographical perception of the protected area and provides an applied science contribution to protected areas research. (in German)

Volume 11: Zwei Alpentäler im Klimawandel/A tale of two valleys. Auer, I., F. Prettenthaler, R. Böhm \& H. Proske (eds.) 2010.

ISBN 978-3-902719-44-7

Using an integrational approach, this book looks at climate and climate change in two adjoining Alpine valleys, the Rauriser Tal in Salzburg and the Mölltal in Carinthia and describes the contrasting strategies of both valleys in handling climate variability and changes in the environment. The inter- and transdisciplinary overall picture emerges through the cooperation of experts in the natural and social sciences, economists and humanities scholars with the local population, with schools, alpine tourist and cultural associations, and local decision makers in business and politics. (in German)

Volume 12: Die Alpen im Wandel zwischen Risiken und Chancen/Le Alpi che cambiano tra rischi e opportunità / Changing Alps between risks and chances. Scaramellini, G. \& A. Giulia Dal Borgo (eds.) 2011. ISBN 978-3-902811-09-7

This volume is a collection of talks given by key players from the spheres of culture, politics and business at the 5th International Conference of Rete Mon- 
tagna in Chiavenna (I) and Castasegna (CH) on Change in the Alps - risks and opportunities. The themes of the papers ranged from the impact of climate change, the use of resources, linguistic and cultural diversity to politics and Alpine governance. (in German, English and Italian)

Volume 13: Coole Forschung: Lernen und Forschen im Internationalen Polarjahr 2007/2008/Cool Research: Learning and Research in the International Polar Year $2007 / 2008$. Schöner, W., S. Prock \& B. Sattler (eds.) 2012.

ISBN 978-3-902811-31-8

This volume presents the activities of the research and education project BiPolar, a cooperation project of science and schools that, taking polar research as a case in point, looked to integrate pupils into research and into developing research questions. It also tested if adolescents, in close cooperation with adults, could take on smaller subprojects of scientific projects and really contribute to state-of-the-art research. (in German)

Volume 14: Ökonomische Strategien des Naturgefahrenmanagements: Konzepte, Erfahrungen und Herausforderungen. Schwarze, R., M. Schwindt, G.G. Wagner \& H. Weck-Hannemann 2012.

ISBN 978-3-902811-60-8

The theme of this book is the economic approach to environmental issues and especially to the challenges of climate and global change. The challenges of natural hazards are treated here with a focus on heavy rain events and floods or landslides that start in the mountains and / or manifest themselves there. The authors concentrate on the economic perspective and the institutional conditions of alternative measures of risk transfer and look at the incentives they offer. (in German)

\section{Contact}

University of Innsbruck

Alpine Space - Man \& Environment

Innrain 52, 6020 Innsbruck, Austria

Homepage:

http://www.uibk.ac.at/alpinerraum/index.html.de e-mail: alpiner-raum@uibk.ac.at, reinhard.lackner@uibk.ac.at

\section{Günter Köck}

Editor eco.mont and coordinator of the national and internationl programmes of the Austrian Academy of Sciences 